\title{
The Chöpfi pinnacles near Winterthur, Switzerland: long-distance effects of the Ries impact-earthquake?
}

The mid-Miocene Ries impact in southern Germany is Central Europe's biggest cosmic disaster in Phanerozoic geologic history. While earlier theories posited the Ries impact was contemporaneous with the smaller nearby Steinheim event in a double-impact scenario, it was recently shown that the Ries, with a Langhian age of 14.81 Ma (Schmieder et al. 2018), predates Steinheim (Serravallian) by a few hundred thousand years (Buchner et al. 2020). In addition to the distribution of impact ejecta, the Ries impact triggered a powerful $\left(\mathrm{M}_{\mathrm{W}} \sim 8.5\right)$ earthquake with far-reaching environmental effects (Buchner et al. 2020).

Geologic traces of the Ries event can be found in sediments of the Upper Freshwater Molasse ("Obere Süßwassermolasse", OSM) within the North Alpine Foreland Basin of southern Germany and northern Switzerland, where coarse-grained distal Ries ejecta form a mid-Miocene marker bed (e.g., Sach 1997; Hofmann 2008). At several localities across the basin, Ries ejecta overlie an at least 3-5 m-thick seismite unit characterized by sedimentary features typical of soft-sediment deformation (Buchner et al. 2020). The most distal effects of the Ries impact in the foreland basin, evidence of ballistic ejecta deposition and seismic shaking, are found within a maximum radial distance of $\sim 180 \mathrm{~km}$ from the crater center (e.g., Buchner et al. 2020).

The 'Chöpfi' $\left(47^{\circ} 31^{\prime} \mathrm{N}, 8^{\circ} 42^{\prime} \mathrm{E}\right.$; Fig. 1A), a group of sandstone pinnacles near Winterthur, are a protected geosite. They occur in OSM sandstones with an estimated age of $15 \mathrm{Ma}$ (Rey et al. 2011; Zingg 2016) that were deposited in the Hörnli alluvial fan (Bolliger 1998). The outcrop features numerous prominent, irregular-shaped, often times nodule-, knob-, and diapir-like, and typically carbonatecemented sandstone pinnacles, some of which are more than a meter tall and several tens of centimeters wide. Many Chöpfi have distinct bulbous heads. Owing to their selective cementation, the pinnacles are seemingly more resistant to erosion compared to the surrounding sandy substrate that has been removed (Zingg 2016). The Chöpfi show no obvious layering within the sandstone but locally subhorizontal fracturing. The sandstone appears internally featureless. The OSM sandstone exposed in the Winterthur area has been placed in the lower MN 6 European Land Mammal Zone (Bolliger 1998), i.e., the Langhian.

The formation of the Chöpfi is still largely enigmatic as this type of sand cementation and pinnacle-like preservation is uncommon in the Molasse. The prevalent formation model appears to be localized carbonate (and clay/marl) cementation, leaving behind the pinnacles as erosional penitents (Zingg 2016). We here present an alternative, event-related origin of the Chöpfi. The largely featureless internal structure of the sandstone that builds up the Chöpfi is consistent with their formation as a seismite, i.e., sediment modified during the passage of high-energy seismic waves. Diapir-like sand intrusions are typical features within the structural inventory of soft-sediment deformation and liquefaction (Montenat et al. 2007). Liquid to ductile sand injections within the host sediment would have contained supersaturated fluids, promoting rapid cementation by carbonate. This process could explain the eyecatching appearance of the Chöpfi, delineating the threedimensional shape of individual sand diapirs (Fig. 1B). As seen elsewhere in the Molasse basin (Buchner et al. 2020), clay-rich subsurface layers (aquitards) can locally increase the amount of fluids within overlying sands, thereby supporting the formation of soft-sediment seismites on an outcrop scale during an earthquake. The rare exposure of

Martin Schmieder $(\varangle) \cdot$ Elmar Buchner

HNU - Neu-Ulm University of Applied Sciences, Wileystraße 1, 89231 Neu-Ulm, Germany

email: martin.schmieder@hnu.de

Volker J. Sach

Fokus Natur, Am Heselsberg 29, 88416 Ochsenhausen, Germany

Received: 18 June 2021 / Accepted: 23 June 2021/ Published online: 2 August 2021

(c) The Author(s) 2021 


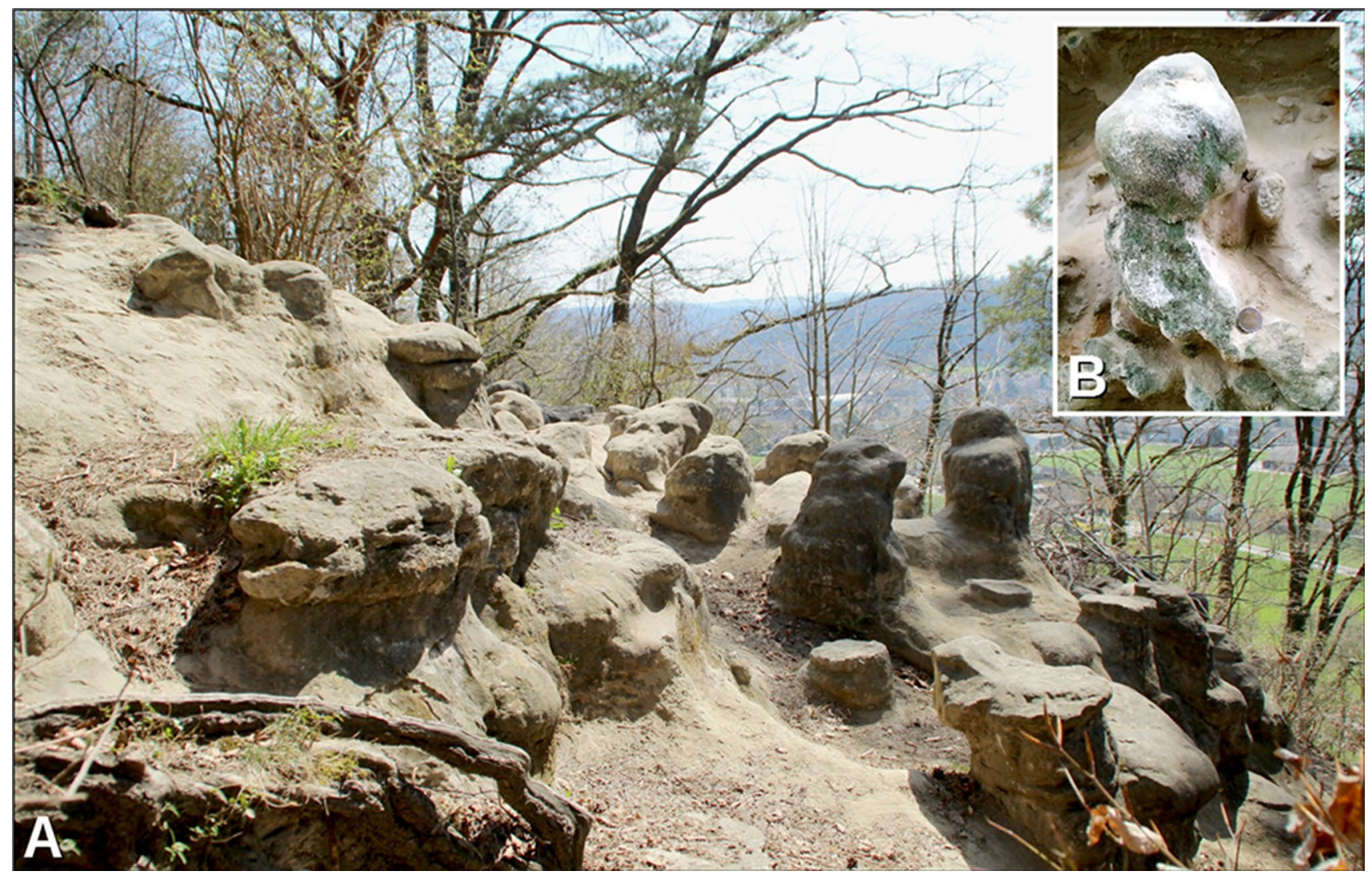

Fig. 1 Diapir-like sandstone pinnacles in Switzerland and Southern Germany. a The 'Chöpfi' in 15 million year-old Upper Freshwater Molasse sandstone near Winterthur, Switzerland. The outcrop features numerous diapir- and knob-like, predominantly carbonatecemented, pinnacles of sandstone. Image: Adrian Michael. b A fossil sand diapir in an exposure of the Ries-seismite near Biberach an

fossil sand diapirs near Winterthur may, therefore, indicate water saturation of the local substrate and its interaction with strong seismic waves.

The estimated stratigraphic age of the Chöpfi host sandstone of $\sim 15$ million years, corresponding to early MN 6 (Bolliger 1998), postdates major seismotectonic activity within the North Alpine Foreland Basin (Keller 2012), but lines up well with the age for the Ries impact (Schmieder et al. 2018). At $\sim 14.81 \mathrm{Ma}$, the local OSM deposits would have been unconsolidated and close enough to the land surface to experience strong seismic soft-sediment deformation, as observed at a number of localities across the basin (Buchner et al. 2020; Sach et al. 2020; Fig. 1B). Located $205 \mathrm{~km}$ southwest of the center of the Ries crater, the Chöpfi may represent the most distal direct effects of the mid-Miocene Ries impact-earthquake that are currently known.

Acknowledgements The authors thank Adrian Michael for making Fig. 1A available under the CC BY-SA 1.0 license. E.B. acknowledges a grant by the Stifterverband für die Deutsche Wissenschaft. der Riß, Germany (compare Buchner et al. 2020). The sand diapir strongly resembles those of the 'Chöpfi' and occurs within sands that show soft-sediment deformation. Due to carbonate cementation, the sand diapir is more resistant to weathering and erosion compared to the surrounding sands. Image: Volker J. Sach

Funding Open Access funding enabled and organized by Projekt DEAL.

Open Access This article is licensed under a Creative Commons Attribution 4.0 International License, which permits use, sharing, adaptation, distribution and reproduction in any medium or format, as long as you give appropriate credit to the original author(s) and the source, provide a link to the Creative Commons licence, and indicate if changes were made. The images or other third party material in this article are included in the article's Creative Commons licence, unless indicated otherwise in a credit line to the material. If material is not included in the article's Creative Commons licence and your intended use is not permitted by statutory regulation or exceeds the permitted use, you will need to obtain permission directly from the copyright holder. To view a copy of this licence, visit http://creativecommons.org/licenses/by/4.0/.

\section{References}

Bolliger T (1998) Age and geographic distribution of the youngest upper freshwater molasse (OSM) of eastern Switzerland. Eclogae Geol Helv 91:321-332 
Buchner E, Sach VJ, Schmieder M (2020) New discovery of two seismite horizons challenges the Ries-Steinheim double-impact theory. Sci Rep 10:4. https://doi.org/10.1038/s41598-020-79032-4

Hofmann BA (2008) Shatter cones aus dem blockhorizont an der Sitter bei Bernhardzell. Ber St. Gallischen Naturwiss Ges 91:77-86

Keller B (2012) Facies of molasse based on a section across the central part of the Swiss plateau. Swiss Bull Angew Geol 17:3-19

Montenat C, Barrier P, Hibsch C (2007) Seismites: an attempt at critical analysis and classification. Sed Geol 196:5-30

Rey R, Wildberger A, Frank S, Freimoser M (2011) Geologischer Atlas der Schweiz, 1:25'000, Karte 140, Blatt 1072 Winterthur, m. Erl

Sach VJ (1997) Neue Vorkommen von Brockhorizonten in der Oberen Süßwassermolasse von Baden-Württemberg
(Deutschland)—Zeugnisse der Rieskatastrophe im Mittelmiozän. N Jb Geol Paläont Abh 205:323-337

Sach VJ, Buchner E, Schmieder M (2020) Enigmatic earthquake-generated large-scale clastic dyke in the Biberach area (SW Germany). Sed Geol 398:13. https://doi.org/10.1016/j.sedgeo.2019.105571

Schmieder M, Kennedy T, Jourdan F, Buchner E, Reimold WU (2018) A high-precision ${ }^{40} \mathrm{Ar} /{ }^{39} \mathrm{Ar}$ age for the Nördlinger Ries impact crater, Germany, and implications for the accurate dating of terrestrial impact events. Geochim Cosmochim Acta 220:146-157

Zingg E (2016) Sandköpfe oder «Chöpfi» - Zeugen einer früheren Zeit. Nagra Blog Erdwissen, 01.11.2016 